Teah, M. and Lwin, M. and Cheah, I. 2014. Moderating role of religious beliefs on attitudes towards charities and motivation to donate. Asia Pacific Journal of Marketing and Logistics. 26 (5): pp. 738-760. 


\section{Moderating Role of Religious Beliefs on Attitudes towards Charities and Motivation to Donate}

\section{Purpose}

The study aims to examine the relationship between image of charitable organizations, attitudes towards charities and motivation to donate. In addition, the study will investigate the moderating effects of religious beliefs on attitudes towards charities and motivation to donate.

\section{Design/methodology/approach}

Data is collected using a self-administered questionnaire. Trained interviewers employed a mallintercept method in downtown Kuala Lumpur over both weekdays and weekends. The scales are adapted from established sources.

\section{Findings}

It was found that religious beliefs moderates the relationship between attitudes towards charities and motivation to donate. In addition, image of charitable organizations has a positive influence on attitudes towards charities. It was also found that both image of charitable organizations and attitudes towards charities influence motivation to donate.

\section{Research limitations/implications}

The study is conducted within downtown Kuala Lumpur and is not generalizable across Malaysia and other countries. In addition, this study only looked at general religious beliefs, therefore findings are not specific to a religion. As a result, possible religious differences may be neglected. Lastly, the study only focused on donors and further studies need to be conducted on non-donors to further understand donation behaviour.

\section{Practical implications}

The findings from the study provide valuable insights to charities, government bodies and policy makers as it highlights the linkages between image of charitable organizations, attitudes towards charities and the motivation to donate of past donors. Additionally, religious bodies can also use the findings to formulate communication strategies to benefit charities as well as the broader community.

\section{Originality/value}

The study provides insights into the motivations of donors to donate to charities. More importantly, it also examines the influence of religious beliefs on donation behaviour, thus shedding insights on the opportunities for fundraising by charities. 


\section{Background}

It has been ten years since the 2004 Boxing Day tsunami rippled through the Indian Ocean. The tragedy observed the empathy and concern of millions of people around the world through their generous donations to support the relief work to the affected countries. In Australia alone, donations were at \$375 million (Wade, 2014); in the US, \$127million was raised (Dickler, 2011); and internationally, a total of US \$14 billion was raised in response to the tragedy (Cosgrave, 2007). At the first instance, many charitable organizations were quick to set up websites for donations to provide humanitarian aid. It was also found that many donors flocked to better known charitable organizations to make their donations (Michel and Rieunier, 2012). However, with the rising number of charitable organizations, there is intense competition for charitable donations (Ranganathan and Henley, 2008; Sargeant, 1999). According to the Charities Aid Foundation (2013b), by 2030 charitable giving could rise to $\$ 224$ billion a year. This forecast is deemed to be achievable, only if the world donates $0.4 \%$ of their average spending to charity (Charities Aid Foundation, 2013b).

When it comes to charitable donations, it is often associated with religion or religious beliefs. In fact, Ranganathan and Henley (2008, p. 1) states that "charity and religion go hand in hand". In addition, doctrines of major religions, such as Christianity, Hinduism, Buddhism and Islam have documented the importance of helping those in need. Therefore, with the understanding that most of the major religions highlight the importance of helping others and charitable actions, it can be assumed that people with religious beliefs and affiliations would donate generously to charitable organizations (Rangathanan and Henley, 2008). However, it has been debatable as to whether religion impacts on acts of charity (Ryckman et al., 2004), due to evidence from past literature showing that people who are religious can be intolerant and less concerned about others (Batson et al., 1993; Fisher et al., 1994). While other studies have found that individuals who are deeply religious are extremely caring and more willing to perform charitable acts (e.g. donations) (Ryckman et al., 2004).

Extant literature reveals that studies on donation behaviour has been a constant interest of researchers for decades (e.g. Guy and Patton, 1989; O’Malley and Andrews, 1983). The plethora of studies on donation behaviour are mostly centred around donation motivations (van Slyke and Brooks, 2005; Kottasz, 2004; Clary and Snyder, 1995); donation decision making process (Hibbert and Horne, 1996; Smith and McSweeney, 2007); influence of perceptual and attitudes on donation behaviour (Sargeant et al., 2005; Webb et al., 2000; 
Radley and Kennedy, 1995); donor characteristics (e.g. Schlegelmilch et al., 1997); blood (e.g. Otto and Bolle, 2011; Glynn et al., 2002) or organ donation (e.g. Ryckman et al., 2004; Lee et al., 1999; Randhawa, 1998). However, there is also an increasing interest on the impact of religion on charitable giving and donation behaviour (e.g. Reitsma et al., 2006; Jackson et al., 1995; Lam, 2002). However, there are still inconsistencies in the findings which leads to a largely fragmented understanding towards the impact of religiosity on charitable giving (Ranganathan and Henley, 2008). Previous studies in the area have predominantly studied the influence of religion or spirituality on organ donation (e.g. Randhawa, 1998; Stephenson et al., 2008) and volunteerism (e.g. Einolf, 2011; Bekkers and Schuyt, 2008; Farmer and Fedor, 2001; Clary and Snyder, 1995). However, associations of religiosity and monetary donations is an area which warrants further investigation (Ranganathan and Henley, 2008). Considering that two-thirds of the world's population holds some form of religious perspective, it is important to further understand the influence of one's religious beliefs on monetary donations and charitable giving (Ranganathan and Henley, 2008). Therefore, this study aims to further bridge the gap between religious beliefs and its relationship with other variables (Ranganathan and Henley, 2008), more specifically with image of charitable organizations, attitudes towards charities and the motivations to donate.

In addition, this study is focused on studying donation behaviour in Malaysia. In 2013, the World Giving Index report ranked Malaysians at the 42th place out of the 160 countries surveyed in terms of generosity towards monetary donations (CAF, 2013a). Malaysia is considered as an Islamic country, however the blend of ethnicities within the country also lends to a blend of the major religions (Wong, 2010). The population have sizeable percentages that are adherents to the four of the world's leading religions, Islam, Buddhism, Hinduism and Christianity (Mokhlis, 2009). Therefore, religious beliefs would play a significant cultural and social role in the donation behaviour (Lau and Tan, 2009; Mokhlis, 2009). Most studies on donation behaviour are conducted predominantly in the western context, such as the United States, Canada, Australia and UK (e.g. Stephenson et al., 2008; Ryckman et al., 2004; Bekkers and Schuyt, 2008; Reitsma et al., 2006). Therefore, this calls for more research to be done on donation behaviour within the Asia region (Lwin, Phau and Lim, 2013). As a result of the multi-racial and multi-culture nature of Malaysia, it is apt to take a more holistic approach on religion and examine the religious beliefs rather than a specific religion (Loch et al., 2010). 
The aims of this study are therefore fourfold. First, it examines the relationship between "image of charitable organizations" and "attitudes towards charities" of Malaysian donors. In order to understand if attitudes will result in motivation to donate, "attitudes towards charities" is tested for its relationship towards "motivation to donate". Thirdly, the study examines if "image of charitable organizations" will influence "motivation to donate". Lastly, and most importantly, it investigates the moderating effects of "religious beliefs" on the relationship between "attitudes towards charities" and "motivation to donate".

This paper will be structured into the following sections, beginning with a review of the extant literature which is followed by the hypotheses development. This is followed by a discussion on the methodology employed in this study. Subsequently, the paper will present the findings and analysis, and discussion on the managerial implications. Lastly, it will conclude with limitations and future directions of the study. 


\section{Relevant Literature Review and Hypotheses Development Theory of Giving Behaviour}

There are a number of theories to understand the motivations behind a charitable donation. One of the prominent theories that is frequently discussed by scholars to explain the concept of charitable donation is the theory of altruism. The theory of altruism explains that charitable donation or a simple act of giving to others is a response to the concern for the welfare of others (Otto and Bolle, 2011; Gates and Steane, 2009; Dixon 2008; Gates and Steane, 2007; Simmons and Emanuele, 2007; Webb et al, 2000). "Altruism" was first conceptualised by Comte $(1858,1865,1891)$ and subsequently scholars have provided numerous definitions of altruism. For example, it is defined as a prosocial action intended to benefit others (Staub 1978; Eisenberg 1986), a cognitive activity to help others by Brewer (2003), an unconditional and conscious action to improve other's welfare (Monroe, 1990), an image by (Hou, Du and Tian 2009), an attitude by Frydman et al. (1995), a motivation by Sober (1990), a helping behaviour Schwartz (1970) and a desire to improve another's condition by Karylowski (1982). Scholars from social-psychology defined altruism as empathetic response, the empathyaltruism hypothesis suggests that individuals are not always self-seeking and they are driven by empathy to help those in need Eveland and Crutchfield, 2007). Altruistic motivation is defined as a helping motive drive by sympathy responding to a request, believing in the cause, and a moral sense of obligation to give back to society (Myers, 1990; Hibbert et al., 2005). These conceptual definitions have given way to what is now known as emotional utility of altruism in the literature.

However, the theory of altruism is questioned by numerous researchers as it does not effectively explain charitable donation behaviour. Research from other disciplines have suggested other methods to explain giving behaviour, for example, the "private consumption" model explains that individuals experience a personal "warm glow" from the act of charitable donation (Handy and Katz, 2007). The volunteering literature shows that donors donating their time and money create a private "warm glow" and also provides a public good to the society (Handy and Katz, 2007). Other scholars have explored other views on the drivers of charitable donations; some suggested that charitable donations is driven by the image of the charitable organization (Hou, Du and Tian, 2009), while others have suggested that charitable donations is driven by normative influences (Heiser 2006), and others have suggested egoistic drivers of donation behaviour (e.g., Batson, 1991). Additionally, there are numerous studies that attempt to explain charitable donations by developing an understanding of the 
characteristics of the charitable donor (e.g. Riecken and Yavas 2005; Sargent, 1999; Dvorak and Toubman, 2013). These conceptual definitions have given way to what is now known as demonstrable utility of altruism in the literature.

\section{Donor Characteristics}

When it comes to understanding donation behaviour and charitable giving, previous research have largely focused on uncovering the relationship between key demographic factors, such as age, gender, marital status, income levels and donation behaviour (Lee et al., 1999; Burgoyne et al., 2005; Dvorak and Toubman, 2013; Riecken and Yavas 2005; Sargeant, 1999). Some studies have found that females are more likely to donate (Roberts and Roberts, 2012; Chang, 2007; Simmons and Emanuele, 2007; Schlegelmilch et al., 1997a), whereas others have found the results to be untrue (Croson and Gneezy, 2009; Dvorak and Toubman, 2013).

In addition, age has been investigated without conclusive results, some studies found that younger individuals are less likely to donate (Smith and McSweeney, 2007), while others found it be insignificant when considering donor characteristic (Louie and Obermiller, 2000). Some studies identified that the likelihood of a donation is up to the age of 65 , beyond this age there is a lower level of donation (Danko and Stanley, 1986; Schlegelmilch and Tynan, 1989; Schlegelmilch et al., 1997b). From another perspective, Radley and Kennedy (1995) states that age and lifecycle affects ones' attitudes and intentions towards giving to charity, because of more matured and worldly views can encourage a householder to become more willing to donate.

Further, charitable donation is frequently shown to have a positive relationship to income (James and Sharpe, 2007) and wealth (Andreoni and Scholz, 1998). Research shows that individuals with more discretionary income are more likely to donate (Schlegelmilch et al., 1997a). In the same vein, individuals with a higher income are more likely to donate to charities that are concerned with the third world and global issues (Kennedy 1995; Bennett 2003). While attempts have been made to profile donors based on demographic characteristics, the exercise has been inconclusive due to inconsistencies across numerous researches. Therefore, more studies are encouraged in order to better understand donation behaviour (Lwin, Phau and Lim, 2013). 


\section{Brand Image of Charities}

According to the American Marketing Association (AMA), a brand is a name, term, sign, drawing or a combination of these that serves to identify a firm's goods or services to differentiate itself from the competitors (AMA; Michel and Rieunier 2012). The concept of brand image in marketing can be dated back to the 1950s where brand image was used to differentiate a firm's product from the competitor's (Padgett and Allen, 1997). There are numerous definitions of brand image, some scholars defined brand image with the idea of brands having a personality (Dobni and Zinkhan, 1990), others defined it as functional, psychological and symbolic attributes and associations (Martineau, 1958; Gardner and Levy 1955) and other have viewed it as, consumer's mental picture of the brand in response to brand-related stimuli (Padgett and Allen, 1997; Shimp 1997; Kotler and Armstrong 1996). Therefore, non-profit image can be defined as, attributes and functional consequences and the symbolic meanings donors associate with a charitable organisation (Michel and Rieunier 2012; Padgett and Allen, 1997).

Branding has become a critical component of the charitable donation industry due to the increasingly competitive nature of the industry (Michel and Rieunier 2012; Bennett and Gabriel 2003). The literature shows the importance of self-image and the charity's image, it proposes that donations are more likely if they two are congruent (Polonsky, 2000). Therefore, charities are differentiating themselves on a number of identifiable, functional and symbolic associations (Hankinson 2001; Keller 1993; Aaker 1991). Despite this, there is limited research on the area of non-profit branding (Michel and Rieunier 2012). Specifically, non-profit brand image is an important concept that marketers and scholars need to address as it has been shown be to a key driver of charitable donations (Hou, Du and Tian 2009; Bennett and Gabriel 2003). Typically a non-profit brand image consists of compassion, dynamism, idealism, beneficiaries and non-political image (Michel and Rieunier 2012). For charitable organisations they create their brand image and associations through the charity's mission and tangible qualities (Michel and Rieunier 2012). Furthermore, these charities also use intangible attributes such as values of the organisation and emotional brand attachment with the brand to differentiate itself from the competitors. As a result, brand image has shown to have positive effect on donation intentions (Hou, Du and Tian 2009).

It is therefore postulated that: 
$\mathrm{H}_{1}$ : Image of charitable organizations will have a significant relationship with attitudes towards charities.

\section{Attitudes towards Charities}

A charity's primary function is to raise funds that enables them to carry out their service for the society, whether it is for the relief of poverty or for the relief of a disaster, or for the welfare of human rights, or for the advancement of education, or for the advancement of religion or for other purposes that are beneficial for the community (Charities Digest, 1995; Knowles et al., 2012). Therefore, creating a favourable attitude is one of the key objectives for charitable organisations as they strive to raise more funds to help them carry out their services for the community. Attitude towards charities is defined as a learned predisposition to respond in a consistently favourable or unfavourable manner towards the charity (MacKenzie and Lutz, 1989). This conceptual definition is well supported by Fishbein and Ajzen's (1975) definition of attitudes. Past studies have indicated that a positive relationship exists between attitude towards the charity and intentions to donate (Lwin and Phau 2014). Similarly, a favourable attitude towards the charity will have a positive effect on motivation to donate. The Theory of Planned Behaviour provides a theoretical foundation on this relationship and explains that a favourable attitudes will result in favourable intentions (Fishbein and Ajzen, 1975). Webb et al. (2000) further reiterates that an individual's attitudes towards charitable organizations correlates with charitable giving, therefore resulting in making donations to charities.

Schlegelmilch et al. (1997a; 1997b) shows the change in the level of involvement and donations from the government, and the public within the charity industry. Traditionally, the government has provided the donations to the needy (Schlegelmilch et al., 1997b), however, due to changing economics and societal values much of the donations come from the public. It is important to understand the "norms" of the donation process (e.g. does the donor perceive that they are liable for the donation? Or is the emphasis on the government?). Thus, this is one of the key variables to help understand how donors' attitudes towards charities effect their motivation to donate.

Furthermore, studies show that charities are operating more like businesses and donors are demanding greater effectiveness from their donations and more clarification on how their donations are being spent (Szper and Prakash, 2011; Dart, 2004; NIPO, 2003). The existing 
perception is that international charities are more efficient as they are able to provide the support for the much needed group of individuals (Bennett, 2003; Sloan, 2009; Szper and Prakash, 2011) and respond to donors' demands. Empirical studies have confirmed that donors value organisation effectiveness and they seek this information internally and externally when making a decision to donate (Iwaarden et al. 2009; William 2007; Schlegelmilch et al., 1997b). One of key issues that is faced by national and international charities is donors' perception on the amount of donations that actually reaches the cause (Szper and Prakash 2011; Gugerty and Prakash 2010). Due to high administration and fundraising costs, donors are uncertain how much of the donations will go to aiding the actual cause. Lack of government legislation and organisational accountability has further heightened this issue. Based on these factors, past studies have shown that attitude towards charity has a positive influence on motivations to donate for international charities (Lwin, Phau, Lim, 2013).

\section{Motivation to Donate}

The keen interest in understanding the key factors and drivers for donors to donate to a cause has been a continuous quest (Sargeant et al., 2005; Dawson, 1988). There are varied reasons why people give to charity. A few that were highlighted by Lasby (2004) includes feeling compassion towards other people; helping the cause in which one personally believes in; you or someone you know is affected by the cause; feel you owe something to your community; fulfil religious obligations or beliefs; and government will give credit on income tax. Guy and Patton (1988) states that people have an innate drive to help others whether it is an intrinsic or extrinsic motivation.

In explaining the various motives for charitable giving, Dawson (1988) categorized the motivations into four categories. They are namely reciprocity motive, self-esteem motive, income or tax motive, and career motive. In addition, Sargeant et al. (2005) states that the motivations to donate are based on the perceptions of the benefits they receive. The benefits that were highlighted are demonstrable, emotional and familial. For example, an individual may be motivated to donate if their donations are acknowledged, or made visible to others within their social group (Stroebe and Frey, 1982). Therefore conveying a demonstrable utility. In giving to a charitable cause, a person may experience emotional benefits that can result in feeling a sense of duty and the satisfaction of helping someone else. These are described as the change in emotions that their act of charity evokes (Sargeant et al., 2005). 
The third type of motivation, which is familial utility stems from the need to help one's friends or loved ones (Sargeant, 1999). It has been recognized that motivations can be a result of one's personal link or experience with a cause, therefore driving them to associate and donate to a particular cause (Kotler and Clark, 1987).

Building on the above discussion, it is postulated that:

$\mathrm{H}_{2}$ : Attitude towards charities will have a significant relationship with motivation to donate. $\mathrm{H}_{3}$ : Image of charitable organizations will have a significant relationship with motivation to donate.

\section{Religious Beliefs}

The concept of religiosity has been defined and many researchers (King and Boyatzis, 2004; Mokhlis, 2009). In addition, religion has been acknowledged by researchers as an important influencer of human behaviour (Lau and Tan, 2009). According to Mokhlis (2009), religion is a cultural factor that is one of the most universal and influential social institutions that has an impact on the behaviour, attitudes and values of an individual and the society as a whole. Scholars have explained that religious belief is a key psychographic characteristic to help determine the differences between donors and non-donors (Ranganathan and Henley, 2008; Simmons and Emanuele, 2012). It is conceptualised that individuals that are perceived to be more religious are more likely to donate (Ranganathan and Henley, 2008). However, there is limited research on this important psychographic characteristic (Lwin, Phau and Lim, 2013). There are some studies that show a number of issues regarding religious ethicalities for organ donations (e.g. Mohammed, 2012; Randhawa et al., 2010). However, there is a lack of research that examine the indirect impact of religious beliefs on motivations to donate.

Schlegelmilch et al. (1997a) clearly highlighted that "donating" is a fundamental religious teachings and thus it is a key consideration when evaluating the influence of religiosity on donation behaviour. Some of the past studies have shown that there is a direct impact between religiosity and attitude towards helping others and attitude towards the charity (Ranganathan and Henley 2008). Studies have also found that religious involvement will have positive influence on various forms of civic behaviour and charitable giving (Perks and Haan, 2010; Jackson et al., 1995; Hodgkinson et al., 1990). Prior research have shown that 
religious Christians were motivated to give for religious reasons and out of their sense of duty to society (Slyke et al., 2005). In addition, McKeown et al (2004) found that donors who held religious beliefs and who attends religious services are the most generous donors. However, others have rejected these findings and found that there are no significant relationships between religiosity and charitable donation in an Australian context (Kanabar, 2004). The findings suggest that there must be more to religious belief than a direct impact on charitable donations. Based on religious teachings, and it is predicted that it could have moderating effect in a charitable donation context. That is, if an individual is bounded by strong religious beliefs, they will value the charity's work even more. As the result, it will increase the likelihood of the donation. According to Ranganathan and Henley (2008), their study found that the higher ones' level of religiosity, it will influence the person to have better attitudes towards charitable organizations and donation intentions. Therefore, it can be argued that religiosity can also play a role in moderating the relationship between attitudes and motivations to donate.

Therefore, it is postulated that:

$\mathrm{H}_{4}$ : Religious beliefs will moderate the relationship between attitudes towards charities and motivation to donate.

\section{Methodology}

\section{Data Collection}

Data was collected using a mall intercept method in downtown Kuala Lumpur, Malaysia. Trained interviewers were given instructions to approach every $5^{\text {th }}$ shopper to cross a designated spot to participate in a self-administered questionnaire. The collection occur across three weeks, covering both weekdays and weekends. Interviewers were also instructed to include respondents from different demographic profiles. This method has proved to be appropriate for data collection for studies on donation behaviour (Lwin, Phau and Lim, 2013; Dawson, 1988).

\section{Survey Instrument}

The survey instrument consists of four sections and was developed using established scales. The questionnaire is made up of four sections and the description of the scale reliabilities and sources are detailed in Table 1. Section A consisted of a screening question measuring the 
respondents past donation behaviour. Section B measured image of charitable organizations and attitudes towards charities. Section $\mathrm{C}$ measured religious beliefs and motivation to donate. Lastly, Section D comprised demographic questions of respondents. All items are measured on a seven-point Likert scale with 1 representing "strongly disagree" and 7 representing "strongly agree".

\section{< Insert Table 1 here >}

\section{Results and Analysis \\ Sample}

A total of 310 questionnaires were collected. Primarily, responses that were incomplete were removed. As this study aims to examine the donation behaviour of donors, the respondents who answered "no" to the screening question asking if they have ever made donations to a charity were discarded. As a result, only 203 useable responses were retained and analysed using SPSS 22.

Based on Table 2, 58.1\% of the donors age between $19-25$. Furthermore, $52.2 \%$ of the donors are females. The majority of the donors (54.7\%) earn RM20, 000 and below per annum. $87.7 \%$ of the donors are from Malaysia. 54.2\% of the donors hold a Bachelor degree, followed by $21.7 \%$ of the donors hold a College Diploma. While the sample distribution has a higher majority of respondents belonging to the younger age groups, according to reports by Charities Aid Foundation (CAF), it was found that there is a growth in charitable acts by individuals in younger age groups e.g. 15 - 24 (Charities Aid Foundation, 2013a). Therefore, this is representative of the possible drift in the ages of donors (Lwin, Phau and Lim, 2013).

\section{$<$ Insert Table 2 here >}

\section{Factor Analysis}

Exploratory factor analysis was independently conducted on the Image of Charitable Organizations, Attitudes towards Charities and Motivation to Donate scale. Through Varimax rotation, two factors emerged for Image of Charitable Organizations and were named "Positive Image" and "Negative Image". Subsequently, Varimax rotation revealed two factors for Attitudes towards Charities which are namely "Government Responsibility" and "International Support". Factor analysis on Motivation to Donate revealed two factors, which 
are "Demonstrable Utility" and "Emotional Utility". The factors were within acceptable range of reliabilities and results are reflected in Table 3. Each of the scales revealed two factors and they are used independently for subsequent analyses.

\section{< Insert Table 3 here >}

\section{Regression Analysis}

\section{Influence of Image of Charitable Organizations on Attitudes towards Charities}

Multiple regression was conducted between "Positive Image", "Negative Image" and "Government Responsibility". The results in Table 4 show that there is a significant negative relationship between "Positive Image" and "Government Responsibility" ( $p<.000, \beta=-.458$, Adj. $\mathrm{R}^{2}=.217$ ) and a significant positive relationship between "Negative Image" and “Government Responsibility" ( $\mathrm{p}<.004, \beta=.182)$.

Multiple regression was conducted between "Positive Image", "Negative Image" and "International Support". It was found that only "Negative Image" has a positive significant relationship towards "International Support" $\left(\mathrm{p}<.010, \beta=.183, \mathrm{Adj} . \mathrm{R}^{2}=.03\right)$. Therefore, results show that "Positive Image" has no significant relationship towards "National/International Support" $(p<.707, \beta=.377)$. As such, $\mathrm{H}_{1}$ is partially supported.

\section{Influence of Attitudes towards Charities on Motivation to Donate}

Multiple regression was conducted between "Government Responsibility", "International Support" and "Demonstrable Utility". Based on the results in Table 4, it was found that "Government Responsibility" ( $p<.011, \beta=-.178)$ and "International Support" $(p<.020, \beta=-$ .162 ) have a significant negative relationship towards "Demonstrable Utility" (Adj. $\mathrm{R}^{2}=.043$ ).

Similarly, multiple regression was conducted between "Government Responsibility", "International Support" and "Emotional Utility". It was found that only "Government Responsibility" has a significant negative relationship towards "Emotional Utility" ( $p<.006$, $\beta=-.224$, Adj. $\left.R^{2}=.043\right)$. The results show that "International Support" has no significant relationship towards "Emotional Utility" $(\mathrm{p}<.666, \beta=.030)$. As such, $\mathrm{H}_{2}$ is partially supported.

\section{Influence of Image of Charitable Organizations on Motivation to Donate}


Multiple regression was conducted between "Positive Image", "Negative Image" and "Demonstrable Utility". It was found that only "Positive Image" has a significant positive relationship towards "Demonstrable Utility" $\left(\beta=.193\right.$, Adj. $\left.\mathrm{R}^{2}=.037\right)$. It was found that "Negative Image" has no significant relationship towards "Demonstrable Utility" $(\mathrm{p}<.088$, $\beta=-.119)$.

Similarly, multiple regression was also conducted between "Positive Image", "Negative Image" and "Emotional Utility". It was found that only "Positive Image" has a significant positive relationship towards "Emotional Utility" $\left(\beta=.294\right.$, Adj. $\left.\mathrm{R}^{2}=.077\right)$. The results show that "Negative Image" has no significant relationship towards "Emotional Utility" ( $p<.908$, $\beta=-.008)$. As such, $\mathrm{H}_{3}$ is partially supported.

\section{Hierarchical Moderated Regression Analysis}

In order to test the moderating role of religious beliefs on the relationship between attitudes towards charities and motivations to donate, an exploratory factor analysis was conducted on the Religious Beliefs scale. Through Varimax rotation, the original 6-item scale was reduced to 5-items with two factors, namely "Positive Religious Beliefs" and "Negative Religious Beliefs". Each of the factors are used independently for subsequent moderation analysis.

\section{$<$ Insert Table 4 here >}

\section{Positive Religious Beliefs}

Hierarchical moderated regression was used to test the moderating role of religious beliefs on the relationship between attitudes towards charities and motivation to donate. Hierarchical moderated regression is employed to detect if the addition of the moderator-independent variable interaction term to the relationship between attitudes towards charities and motivation to donate will result in a significant $R^{2}$ change (Anderson 1986). Based on the results in Table 5, it is found that only "Positive Religious Beliefs" moderates the relationship between "International Support" and "Demonstrable Utility" $\left(\mathrm{p}<.003, \Delta \mathrm{R}^{2}=.041, \beta=.710\right)$. "Positive Religious Beliefs" was not found to be a moderator on the relationship between “Government Responsibility” and "Demonstrable Utility”. 
In addition, it was also found that "Positive Religious Beliefs" does not moderate the relationship between "Government Responsibility" and "Emotional Utility". Similarly, it was also found that "Positive Religious Beliefs" does not moderate the relationship between "International Support" and "Emotional Utility".

\section{< Insert Table 5 here >}

\section{Negative Religious Beliefs}

Based on the results in Table 6, "Negative Religious Beliefs" was found to be a moderator for two relationships. Hierarchical moderated regression was conducted on "Negative Religious Beliefs", "Government Responsibility", "International Support", and "Demonstrable Utility". It was found that "Negative Religious Beliefs" moderates the relationship between “International Support" and "Demonstrable Utility" $\left(\mathrm{p}<.007, \Delta \mathrm{R}^{2}=.033, \beta=.272\right)$. However, no significant moderating relationship was found for the effect of "Negative Religious Beliefs" on "Government Responsibility" and "Demonstrable Utility".

It was also found that "Negative Religious Beliefs" moderates the relationship between "International Support" and "Emotional Utility" ( $\left.\mathrm{p}<.024, \Delta \mathrm{R}^{2}=.025, \beta=-.623\right)$. However, "Negative Religious Beliefs" was not found to be a significant moderator between “Government Responsibility" and "Emotional Utility". Based on the results above, $\mathrm{H}_{4}$ is partially supported.

\section{< Insert Table 6 here >}

\section{Discussion and Implications}

The findings from this study has shed interesting insights into the psychological makeup of donors, more specifically the donors from Malaysia. The results showed that image of charitable organizations has a significant relationship with attitudes towards charities. In fact, the finding suggests that the government needs to put in more effort in helping charities and the people in need. In fact, the views are that the government is taking insufficient action to help those in need. Similar to studies from numerous countries, individuals believe that government should be doing more to help those in need rather than solely depending on the public to do so (Hall et al., 2000). Along a similar vein, donors who have a negative image 
towards charities also share the perspective that government responsibility towards charities is lacking (Smith and McSweeney, 2007). While the relationship may not be causal, it can be argued that donors hold negative views towards the lack of government support and input into charities. In order to improve donations, government departments will need to take the lead. In fact, better outcomes can be achieved if CSR is also practiced from a governmental point of view. This could be a potential political campaign for the government to win votes in the upcoming election.

It was interesting to find that negative image towards charities lead to more positive attitudes towards international support. The general perception of local charities is that they are susceptible to wasting resources. It is perceived that international or oversea charities perform better at helping the needy more effectively (Schlegelmilch et al., 1997a). This is an important insight for domestic/local charities or all charities to manage their brand image and perceptions. This is a reflection for the local/domestic charities, who need to change the brand image and perception of their efficiencies by becoming more transparent with their processes. Effective communication strategies with existing and potential donors need to be in place to be able to encourage a positive image of charities and to help the local community more effectively. Efficient communication by providing donor feedback is crucial to building strong emotional bonds to a charitable organization (Merchant et al., 2010; Michel and Rieunier, 2012) and therefore building sustainable relationships with donors.

The results highlighted that government responsibility does not hold a positive relationship towards the demonstrable utility of motivation to donate. This therefore highlights a fundamental psychological issue, that is, because the government is doing so little to help charities and the needy, it is therefore logical for a citizen to donate to help others. This concept is well supported by the normalization theory, which explains that ideas or actions that are perceived to be normal is shaped by our society (May et al. 2009). As a result, the government needs to be more involved with the donation process to provide an incentive to the donors. It needs to be "seen" in public as an exemplar to demonstrate that Malaysians also need to support local and international charities. Based on the results, the donations from current donors are mainly due to their own initiatives rather than seeking assurance and recognition from work, co-workers and to increase their business networks. Therefore, the donation culture can be encouraged, and donors and potential donor can possibly receive positive emotional incentives by doing "good" for the community. Similarly, even when 
donations are made to overseas or international charities, there is very little motivation in terms of external incentives that donors can receive.

In addition, attitudes towards charities in particular government responsibility is shown to have a negative influence towards motivation to donate. This finding reiterates the lack of government involvement and the perceived lack of help from the government towards charities and people in need. Therefore, in turn influences the emotional utility derived from donating as they feel the lack of government support for the causes people believe in, the sense of personal satisfaction and the duty of civic responsibility to be a Good Samaritan. Advertising appeals can highlight the importance of an individual and the relationship to society at large, thereby making the process of giving a personal act (Radley and Kennedy, 1995).

Interestingly, it is found that image of charitable organizations play an important role in encouraging donation behaviour. In fact, when donors perceive a positive image towards charitable organizations, they are more likely to achieve demonstrable utility. This is when the charities that they are involved in has a positive image of helping the needy and doing "good" for the society, and in turn translates these positive associations to the donor by achieving recognition and rewards. In addition, image also plays a key role in influencing emotional utility. When the image of charitable organizations is positive, donors feel a sense of personal satisfaction and a sense of duty to society, in turn the feeling that a worthy cause is being supported. Therefore, it is important to maintain transparency between the operations of a charity and the communication of these operations to donors and potential donors. Therefore, crafting messages to show the outcomes of various programmes can highlight the effectiveness of the donation. The fact is that individuals like to see charities making a positive change, which means there needs to be more programmes involving the local community. This will help maintain engagement with the charity. As such, there is potential for local charities to encourage local communities to be part of their programmes and enhance their connection with the charity (Radley and Kennedy, 1995).

One of the key contributions of this study is to examine the moderating effects of religious beliefs on attitudes towards charities and motivation to donate. Religious beliefs is found to be a significant moderator. This therefore highlights the importance of individual's religious beliefs and their donation behaviour. Positive religious beliefs only moderates the 
relationship between international support and demonstrable utility, which means that donors with religious beliefs are more motivated to donate. Donors with positive religious beliefs will also be more likely to feel that donating to international charities can build important business contacts and gain recognition from employers and co-workers. Previous studies have highlighted the importance of crafting promotional messages that are aligned to the motivations of the donors (e.g Clary and Snyder, 1995). Therefore, for donors with strong religious beliefs, it is important to tailor to the messages that align with the doctrines of their religion.

Interestingly, even with negative religious beliefs, it was found to enhance the relationship between international support and demonstrable utility. This was found to be a weaker relationship as compared to positive religious beliefs. Therefore suggesting that international charities are overall better perceived and the value of supporting international charities can achieve outcomes such as recognition and develop networks and business contacts. This has important implications for international charities as they are seen to be more efficient and are better at managing funds to help those in need. Therefore, for local charities, it is important to portray the image that the charity is helping the needy efficiently. This can be done through newsletters and communicating with donors by updating them on a regular basis. Within the communication programmes, it is important to acknowledge and provide recognition to the individuals who have donated and making mentions of their achievements would highlight the demonstrable utility and allow donors to receive recognition from peers. By providing such recognition, it highlights the good feelings associated with charitable donation (Clary and Snyder, 1995).

Negative religious beliefs has a negative moderating role between international support and emotional utility. While donors supporting international charities are a result of civic responsibility and personal satisfaction, if donors have negative religious beliefs, it would result in a negative impact on the relationship between international support and emotional utility. Therefore, religious beliefs are important when it comes to emotional utility. It can affect the self-empowerment of individuals as they feel it is their own duty to donate and are rewarded by a sense of satisfaction. Therefore, when crafting communication programmes it is important to note the difference between donors who are religious and those who are not. 


\section{Concluding Comments}

It is evident from the results that image towards charitable organizations, attitudes towards charities has a positive influence on the motivations to donate. More importantly, religious beliefs is found to be a significant moderator to encourage donations. Therefore, this finding is in alignment with previous studies emphasizing the importance of religious beliefs on donation behaviour (e.g. Ranganathan and Henley, 2008; Reitsma et al., 2006; Jackson et al., 1995).

However, there are a number of limitations from this study that is worth noting. The research is conducted using a mall-intercept method in downtown Kuala Lumpur, as mostly young consumers will be the ones who are available especially during working hours to participate in the study, there is a possible bias in terms of a younger donor group. The mall intercept method may limit the population that is reached for this study (Phau and Teah, 2009). In addition, the questions regarding donation behaviour and government support may draw social desirability bias. During the time when data was collected, it was noted that there may be negative sentiments towards the government which may bias consumer responses to questions pertaining to views on government responsibility. The findings of this study is also limited to the capital city of Malaysia, which is not generalizable to other parts of Malaysia. The study also did not study specific religions, but only focused on holistic religious beliefs, therefore future studies can examine specific religions and influences on donation behaviour (Mokhlis, 2009).

Further research should focus on younger donors especially when findings suggests that donation behaviour of the older age groups have begun to stagnate (CAF, 2013b). Recent reports have highlighted the growth of youth donations and volunteering due to greater exposure and education of global issues and welfare. Other personality and social factors should also be studied (e.g. guilt and normative influences). In fact, specific charities and donation behaviour can be observed and compared to gauge possible behavioural differences. Other studies can also compare the behavioural differences between donors and non-donors (Ranganathan and Henley, 2008; Lwin, Phau and Lim, 2013).

Instead of studying religious beliefs, future studies can examine spirituality as opposed to religious beliefs as there are key differences between the two. For example, a person can be spiritual without being religious. Therefore, the differences can present further insights into 
the impact of religiosity and spirituality on donation behaviour. Lastly, it is important to note the difference between people who are in a religion and those who are religious. Individuals who are religious would largely adhere to the teachings of the religion, whereas individuals in a religion may just feel an affiliation and association with the religion but may not adhere to the lifestyle and the religious teachings (Bekkers and Schuyt, 2008). Therefore, this is an important difference to be taken into account for future studies. 


\section{References}

Aaker, D.A. (1991), Managing Brand Equity. The Free Press, New York.

American Marketing Association (AMA), (1995), "AMA dictionary", available at https://www.ama.org/resources/Pages/Dictionary.aspx?dLetter=B (accessed 10 August 2014).

Anderson, C. H. (1986). "Hierarchical Moderated Regression Analysis: A Useful Tool for Retail Management Decisions", Journal of Retailing, Vol. 62, Iss. 2, pp. 186 - 203.

Andreoni, J. and Scholz, J. (1998), "An econometric analysis of charitable giving with interdependent preferences", Economic Inquiry, Vol. 36, pp. 410-428.

Batson, C.D. (1991), The Altruism Question: Toward a Social Psychological Answer, L. Erlbaum, Hillsdale, NJ.

Batson, C. D., Schoenrade, P. A. and Ventis, W. L. (1993). Religion and the individual. New York, NY: Oxford University Press.

Bekkers, R. and Schuyt, T. (2008). "And who is your neighbour? Explaining denominationa differences in charitable giving and volunteering in the Netherlands", Review of Religious Research, Vol. 50, Iss. 1, pp. $74-96$.

Bennett, R. (2003), "Factors underlying the inclination to donate to particular types of charity", International Journal of Nonprofit and Voluntary Sector Marketing, Vol. 8 No. 1, pp. 12-29.

Bennett, R. and Gabriel, H. (2003), "Image and reputational characteristics of UK charitable organizations: an empirical study", Corporate Reputation Review, Vol. 6 No.3, pp. 276289.

Brewer, G.A. (2003), "Building social capital: civic attitudes and behavior of public servants", Journal of Public Administration Research and Theory, Vol. 13 No. 1, pp. 5-26.

Burgoyne, C.B., Young, B. and Walker, C.M. (2005). "Deciding to give to charity: A focus group study in the context of the household economy", Journal of Community and Applied Social Psychology, Vol. 15, pp. $383-405$.

Capizzi, M.T. and Ferguson, R. (2005), "Loyalty trends for the twenty-first century", Journal of Consumer Marketing, Vol. 22 No. 2, pp. 72-80.

Charities Aid Foundation (2013a). World Giving Index 2013: A global view of giving trends. Available: https://www.cafonline.org/publications/2013-publications/world-givingindex-2013.aspx

Charities Aid Foundation (2013b). Future World Giving - Unlocking the potential of global philantrophy. Available: https://www.cafonline.org/publications/2013-

publications/future-world-giving.aspx

Charities Aid Foundation (2013c). Growing Up Giving - Insights into how young people feel about charity. Available: https://www.cafonline.org/pdf/Growing_Up_Giving.pdf 
Charities Digest (1995), Charities Digest, available at: www.charitychoice.co.uk/

Clary, E. G. and Snyder, M. (1995). "Motivations for volunteering and giving: A functional approach", New Directions for Philanthropic Fundraising, Vol. 8, Iss. Summer, pp. 111 $-123$.

Comte, A. (1858), The Catechism of Positive Religion, John Chapman, London (translated by R. Congreve).

Comte, A. (1865), A General View of Positivism, Trubner and Co, London (translated by J.H. Bridges).

Comte, A. (1891), The Catechism of Positive Religion, 3rd ed., Kegan Paul, London (translated by R. Congreve, 1st published in French 1852, in English tr. 1858).

Cosgrave, J. (2007). "Tsunami Evaluation Coalition, Synthesis Report: Expanded Summary, Joint evaluation of the international response to the Indian Ocean tsunami". TEC Tsunami Evaluation Coalition. Available: http://www.alnap.org/resource/5536

Croson, R. and Gneezy, U. (2009), "Gender differences in preferences", Journal of Economic Literature, Vol. 47 No. 2, pp. 1-27.

Danko, W.D. and Stanley, T.J. (1986), "Identifying and reaching the donation prone individual: a nationwide assessment", Journal of Professional Services Marketing, Vol. 2 No. 1/2, pp. 117-122.

Dart, R. (2004), 'Being 'business-like' in a non-profit organization: a grounded and inductive typology", Nonprofit and Voluntary Sector Quarterly, Vol. 33 No. 2, pp. 290-310.

Dawson, S. (1988). "Four motivations for charitable giving: Implications for marketing strategy to attract monetary donations for medical research", Journal of Health Care Marketing, Vol. 8, Iss. 2, pp. $31-37$.

Dobni, D. and Zinkhan, G.M. (1990), "In search of brand image: a foundation analysis," in Advances in Consumer Research, Vol. 17, Marvin Goldberg, Gerald Gom, and Richard Pollay, eds., Association for Consumer Research, Ann Arbor, Michigan, pp. 110-119.

Dickler, J. (2011). "Donations to Japan lag far behind Haiti or Katrina”, CNN Money, March 18. Available: http://money.cnn.com/2011/03/18/pf/japan_earthquake_aid/

Dixon, T. (2008), The Invention of Altruism: Making Moral Meanings in Victorian Britain, Oxford University Press, Oxford

Dvorak, T. and Toubman, S.R. (2013), “Are women more generous than men? Evidence from alumni donations", Eastern Economic Journal, Vol. 39, pp. 121-131.

Einolf, C.J. (2011). "Gender differences in the correlates of volunteering and charitable giving”, Nonprofit and Voluntary Sector Quarterly, Vol. 40, Iss. 6, pp. $1092-1112$. 
Eisenberg, N. (1986), Altruistic Emotion, Cognition, and Behavior, Lawrence Erlbaum Associates, Hillsdale, NJ.

Eveland, V. and Crutchfield, T. (2007), "Understanding why people do not give: strategic funding concerns for AIDS related nonprofits", International Journal of Nonprofit and Voluntary Sector Marketing, Vol. 12 No. 1, pp. 1-12.

Farmer, S.M. and Fedor, D.B. (2001). "Changing the focus on volunteering: An investigation of volunteers' multiple contributions to a charitable organization", Journal of Management, Vol. 27, pp. $191-211$.

Fishbein, M. and Ajzen, I. (1975), Belief, Attitude, Intention, and Behavior: An Introduction to Theory and Research, Addison-Wesley, Reading, Massachusetts.

Fisher, R.D., Derison, D., Polley, C. F. III, Cadman, J. and Johnston, D. (1994).

"Religiousness, religious orientation, and attitudes towards gays and lesbians", Journal of Applied Social Psychology, Vol. 24, pp. $614-630$.

Frydman, M., Ledruc, I., Hofmans, V. and Molinier, C. (1995), "The development of altruistic attitudes", Enfance, Vol. 1, pp. 89-100.

Gardner, B.B and Levy, S.J. (1995), "The product and the brand", Harvard Business Review, Vol. 33 No. March/April, pp. 33-39.

Gates, D.K. and Steane, P. (2007), "Historical origins and development of economic rationalism”, Journal of Management History, Vol. 13 No. 4, pp. 330-358.

Gates, D.K. and Steane, P. (2009), "Altruism - an alternative value in policy formation and decision making”, International Journal of Social Economics, Vol. 36 No. 10, pp. $962-$ 978.

Glynn, S.A., Kleinman, S.H., Schreiber, G.B., Zuck, T., McCombs, S., Bethel, J., Garratty, G. and Williams, A.E. (2002). "Motivations to donate blood: Demographic comparisons", Transfusion, Vol. 42, pp. 216 - 225.

Guy, B. and Patton, W. (1988). "The marketing of altruistic causes: Understanding why people help", The Journal of Services Marketing, Vol. 2, Iss. 1, pp. 5 - 16.

Guy, B.S. and Patton, W.E. (1989). "The marketing of altruistic causes: Understanding why people help", The Journal of Consumer Marketing, Vol. 6, Iss. 1, pp. 19 - 30.

Hall, M., Greenberg, L. and McKeown, L. (2000). Talking About Charities: Canadians' Opinions on Charities and Issues Affecting Charities. Edmonton: Canadian Centre for Philanthropy.

Handy, F. and Katz, E. (2008), "Donating behavior: if time is money, which to give? A preliminary analysis", Journal of Economic Studies, Vol. 35 No. 4, pp. 323-332. 
Hankinson, P. (2001), "Brand orientation in the charity sector: A framework for discussion and research", International Journal of Nonprofit and Voluntary Sector Marketing, Vol. 6 No. 3, pp. 231-242.

Hankinson, P. and Rochester, C. (2005), "The face and voice of volunteering: A suitable case for branding?", International Journal of Nonprofit and Voluntary Sector, Vol. 10, Iss. 2, pp. $93-105$.

Heiser, R.S. (2006), "Normative influences in donation decision", Journal of Nonprofit and Public Sector Marketing, Vol. 15 No. 1/2, pp. 127-149.

Hibbert, S. and Horne, S. (1996). "Giving to charity: questioning the donor decision process", Journal of Consumer Marketing, Vol. 13, Iss. 2, pp. 4 - 13.

Hibbert, S., Horne, S. and Tagg, S. (2005), "Charity retailers in competition for merchandise: examining how consumers dispose of used goods", Journal of Business Research, Vol. 58, pp. 819-828.

Hodgkinson, V., Weitzman, M. and Kirsh, A. (1990). "From commitment to action: How religious involvement affects giving and volunteering", In Wuthnow R. \& Hodgkinson V.A. (Eds.), Faith and philanthropy in America, pp. 93 - 114. San Franscisco: JosseyBass.

Hou, J., Du, L. and Tian, Z. (2009), "The effects of nonprofit brand equity on individual giving intention: mediating by the self-concept of individual donor", International Journal of Nonprofit and Voluntary Sector Marketing, Vol. 14 No. 3, pp. 215-229.

Iwaarden, J., Wiele, T., Williams, R. and Moxham, C. (2009), "Charities: how important is performance to donors", International Journal of Quality and Reliability Management, Vol. 26 No. 1, pp. 5-22

Jackson, E. F., Bachmeier, M.D., Wood, J.R. and Craft, E.A. (1995). "Volunteering and charitable giving: Do religious and associational ties promote helping behaviour?", Nonprofit and Voluntary Sector Quarterly, Vol. 24, No. 1, pp. 59 - 78.

James, R.N. and Sharpe, D.L. (2007), "The nature and causes of the U-shaped charitable giving profile”, Nonprofit and Voluntary Sector Quarterly, Vol. 36 No. 2, pp. 218-238.

Kanabar, T. (2004), "Characteristics affecting charitable donations in Australia".

Karylowski, J. (1982), “Two types of altruistic behavior: doing good to feel good or to make the other feel good", in Derlega, V.J. and Grzelak, J. (Eds), Cooperation and Helping Behavior: Theories and Research, Academic Press, New York.

Keller, K.L. (1993), "Conceptualizing, measuring and managing customer-based brand equity”, Journal of Marketing, Vol. 57 No.1, pp. 1-22.

King, P.E. and Boyatzis, C.J. (2004), "Exploring adolescent spiritual and religious development: Current and future theoretical and empirical perspectives", Applied Developmental Science, Vol. 8, Iss. 1, pp. 2-6. 
Knowles, S.R., Hyde, M.K. and White, K.M. (2012), "Predictors of young people's charitable intentions to donate money: an extended theory of planned behavior perspective", Journal of Applied Social Psychology, Vol. 42 No. 9, pp. 2096-2110.

Kotler, P. and Armstrong, G. (1996), Principles of Marketing, Prentice Hall, Englewood Cliffs, NJ.

Kotler, P. and Clarke, R.N. (1987). Marketing for health care organizations. Englewood Cliffs, NJ: Prentice Hall.

Kottasz, R. (2004). "How should charitable organisations motivate young professionals to give philanthropically?", International Journal of Nonprofit and Voluntary Sector Marketing, Vol. 9, Iss. 1, pp. 9 - 27.

Lam, P.Y. (2002). "As the flocks gather: How religion affects voluntary association participation”, Journal for the Scientific Study of Religion, Vol. 41, Iss. 3, pp. $405-422$.

Lasby, D. (2004). The Volunteer Spirit in Canada: Motivations and Barriers. Toronto: Canadian Centre for Philanthropy.

Lau, T.C. and Tan, B. C. (2009), "Religiosity as an antecedent of attitude towards green products: An exploratory research on young Malaysian consumers", Asean Marketing Journal, Vol. 1, Iss. 1, pp. $29-36$.

Lee, L., Piliavin, J.A. and Call, V.R. (1999). "Giving time, money, and blood: Similarities and differences”, Social Psychology Quarterly, Vol. 62, pp. 276 - 291

Loch, A., Hilmi, I.N., Mazam, Z., Pillay, Y. and Choon, D.S.K. (2010). "Differences in attitude towards cadaveric organ donation: Observations in a multiracial Malaysian society”, Hong Kong Journal of Emergency Medicine, Vol. 17, Iss. 3, pp. 236 - 243.

Louie, T. and Obermiller, C. (2000), "Gender stereotypes and social desirability effects on charity donation", Journal of Psychology and Marketing, Vol. 17 No. 2, p. 121-136.

Lwin, M., Phau, I. and Lim, A. (2013), "Charitable donations: empirical evidence from Brunei”, Asia-Pacific Journal of Business Administration, Vol. 5 No. 3, pp. 215-233.

Lwin, M. and Phau, I. (2014), "An exploratory study of existential guilt appeals in charitable advertisements", Journal of Marketing Management, DOI: 10.1080/0267257X.2014.939215

MacKenzie, S.B. and Lutz, R.J. (1989), “An empirical examination of the structural antecedents of attitude toward the ad in an advertising pretesting context", Journal of Marketing, Vol. 53 No. 2, pp. 48-65.

Martineau, P. (1958), "The Personality of the Retail Store", Harvard Business Review, Vol. 32 No. October, 47-55. 
May, C.R., Mair, F., Finch, T., MacFarlane, A., Dowrick, C., Treweek, S., Rapley, T., Ballini, L., Ong, B.N., Rogers, A., Murray, E., Elwyn, G., Légaré, F., Gunn, J. and Montori, V.M. (2009). "Development of a theory of implementation and integration:

Normalization Process Theory”, Implementation Science, Vol. 4 Iss. 29, DOI: 10.1186/17485908-4-29.

McKeown, L., McIver, D., Moreton, J. and Rotondo, A. (2004). Giving and Volunteering: The Role of Religion. Toronto: Canadian Centre for Philanthropy.

Merchant, A., Ford, J. and Sargeant, A. (2010). "Charitable organizations' storytelling influence on donors' emotions and intentions”, Journal of Business Research, Vol. 63, Iss. 7 , pp. $754-762$,

Michel, G. and Rieunier, S. (2012), "Nonprofit brand image and typicality influences on charitable giving", Journal of Business Research, Vol. 65 No. 5, pp. 701-707.

Mohammed, G. (2012), "Religio-ethical discussions on organ donation among Muslims in Europe: an example of transnational Islamic bioethics", Medicine, Healthcare and Philosophy, Vol. 15 No. 2, pp. 207-220.

Mokhlis, S. (2009), "Religious differences in some selected aspects of consumer behaviour: A Malaysian study", The Journal of International Management Studies, Vol. 4, Iss. 1, pp. $67-76$.

Monroe, K.R. (1990), “Altruism and the theory of rational action: rescuers of Jews in Nazi-Europe”, Ethics, Vol. 101 No. 1, pp. 103-122.

O’Malley, M.N. and Andrews, L. (1983). "The effect of mood and incentives on helping: Are there some things money can't buy?", Motivation and Emotion, Vol. 7, Iss. 2, pp. 179 189.

Otto, P.E. and Bolle, F. (2011), "Multiple facets of altruism and their influence on blood donation", The Journal of Socio-Economics, Vol. 40 No. 5, pp. 558-563.

Padgett, D. and Allen, D. (1997), "Communicating experiences: A narrative approach to creating service brand image”, Journal of Advertising, Vol. 26 No. 4, pp. 49-62.

Perks, T. and Haan, M. (2010), "Youth Religious Involvement and Adult Community Participation: Do Levels of Youth Religious Involvement Matter?". Nonprofit and Voluntary Sector Quarterly, pp. $1-23$.

Phau, I. and Teah, M. (2009). "Devil Wears (Counterfeit) Prada: A Study of Antecedents and Outcomes of Attitudes Towards Counterfeits of Luxury Brands". Journal of Consumer Marketing, Vol. 26, Iss. 1, pp. 15-27.

Polonsky, M. (2000), "Helping behaviour models - are they appropriate in Australia?", in O'Cass, A. (Ed.), Australian and New Zealand Marketing Academy Conference, Queensland. 
Radley, A. and Kennedy, M. (1995). "Charitable giving by individuals: A study of attitudes and practice”, Human Relations, Vol. 48, Iss. 6, pp. 685 - 709.

Randhawa, G. (1998), "An exploratory study examining the influence of religion on attitudes towards organ donation among the Asian population in Luton, UK", Nephrology Dialysis Transplantation, Vol. 13, pp. 1949 - 1954.

Randhawa, G., Brocklehurst, A., Pateman, R., Kinsella, S. and Parry, V. (2010), "Opting-in or opting-out? - the views of the UK's faith leaders in relation to organ donation", Health Policy, Vol. 96 No. 1, pp. 36-44.

Ranganathan, S.K. and Henley, W.H. (2008), "Determinants of charitable donation intentions: a structural equation model", International Journal of Nonprofit and Voluntary Sector Marketing, Vol. 13 No. 1, pp. 1-11.

Reitsma, J., Scheepers, P. and Te Grotenhuis, M. (2006). "Dimensions of individual religiosity and charity: Cross-national effect differences in European countries", Review of Religious Research, Vol. 47, Iss. 4, pp. 347 - 362.

Riecken, G. and Yavas, U. (2005), "The attitudes of donors and non-donors to the March of Dimes charity in the United States: a case study in non-profit marketing", International Journal of Management, Vol. 22 No. 4, pp. 572-581.

Roberts, J.A. and Roberts, C.R. (2012), "Money matters: does the symbolic presence of money affect charitable giving and attitudes among adolescents?", Young Consumers: Insight and Ideas for Responsible Marketers, Vol. 13 No. 4, pp. 329-336.

Ryckman, R. M., Thornton, B., van den Borne, B., and Gold J. A. (2004). "Intrinsic-Extrinsic Religiosity and University Students' Willingness to Donate Organs Posthumously", Journal of Applied Social Psychology, Vol. 34, Iss. 1, pp. 196 - 205

Sargent, A. (1999), "Charitable giving: towards a model of donor behaviour", Journal of Marketing Management, Vol. 15 No. 40, pp. 215-238.

Schlegelmilch, B.B., Diamantopoluos, A. and Love, A. (1997a), "Characteristics affecting charitable donations: empirical evidence from Britain", Journal of Marketing Practice: Applied Marketing Science, Vol. 3 No. 1, pp. 14-28.

Schlegelmilch, B.B., Love, A. and Diamantopoluos, A. (1997b), "Response to different charity appeals: the impact of donor characteristics on the amount of donations", European Journal of Marketing, Vol. 31 No. 8, pp. 548-560.

Schwartz, S.H. (1970), "Elicitation of moral and self-enhancing behavior, an experimental study of volunteering to be a bone marrow donor", Journal of Personality and Social Psychology, Vol. 15 No. 4, pp. 283-293.

Shimp, T.A. (1997), Advertising, Promotion and Supplemental Aspects of Integrated Marketing Communications, Dryden, Fort Worth, Texas. 
Simmons, W. and Emanuele, R. (2007), "Male-female giving differentials: are women more altruistic?", Journal of Economic Studies, Vol. 34 No. 6, pp. 534-550.

Simmons, W. and Emanuele, R. (2012). Giving patters by religious and non-religious people. The Journal of Applied Business Research, Vol. 28 No. 6, pp. 1243-1251.

Sloan, M. (2009), "The effects of nonprofit accountability ratings on donor behavior", Nonprofit and Voluntary Sector Quarterly, Vol. 28 No. 2, pp. 220-236.

Smith, J.R. and McSweeney, A. (2007), "Charitable giving: the effectiveness of a revised theory of planned behavior model in predicting donating intentions and behavior", Journal of Community \& Applied Social Psychology, Vol. 17, pp. 363-386.

Sober, E. (1990), “What is psychological egoism?”, Behaviorism, Vol. 17, pp. 89-102.

Spzer, R. and Prakash, A. (2011), "Charity watchdogs and the limits of information-based regulation”, Voluntas, Vol. 21, pp. 112-141.

Staub, E. (1978), Positive Social Behavior and Morality: Personal and Social Influences, Vol. 1, Academic Press, New York.

Stephenson, M.T., Morgan, S.E., Roberts-Perez, S. D., Tyler, H., Walid, A. and Long, S. D. (2008). "The role of religiosity, religious norms, subjective norms, and bodily integrity in signing an organ donor card", Health Communications, Vol. 23, Iss. 5, pp. 436 - 447.

Stroebe, W. and Frey, B.S. (1982). "Self-interest and collective action: the economics and psychology of public goods", British Journal of Social Psychology, Vol. 21, pp. 121 137.

Van Slyke, D.M. and Brooks, A. C. (2005). "Why do people give?: New evidence and strategies for nonprofit managers", The American Review of Public Administration, Vol. 35 , pp. $199-222$.

Wade, M. (2014). "Donating: Charity begins at disasters, ends at war", The Sydney Morning Herald, March 16. Available: http://www.smh.com.au/comment/donating-charitybegins-at-disasters-ends-at-war-20140315-34t16.html

Webb, D.J., Green, C.I. and Brashear, T.G. (2000). "Development and validation of scales to measure attitudes influencing monetary donations to charitable organizations", Journal of the Academy of Marketing Science, Vol. 28, Iss. 2, pp. 299 - 309.

Wong, L.P. (2010), "Information needs, preferred educational messages and channel of delivery, and opinion on strategies to promote organ donation: a multicultural perspective", Singapore Medical Journal, Vol. 51, Iss. 10, pp. 790 - 795. 